\title{
Assessment of computer technology availability, accessibility and usage by Agricultural Education student teachers in secondary schools in Botswana
}

\author{
Hulela, K.*, Rammolai, M. and Mpatane, W. \\ Department of Agricultural Economics, Education and Extension Botswana College of Agriculture, \\ Private Bag 0027, Gaborone, Botswana.
}

Received 17 February, 2014; Accepted 30 July, 2014

\begin{abstract}
This study examines the availability, accessibility and usability of computer as a form of information and communication technologies (ICTs) by student teachers in secondary schools. 44 out of 51 student teachers of Agriculture responded to the questionnaire. Means and percentages were used to analyze the data to establish the availability, accessibility and usability of computer technology in schools. The results showed that teachers' computers were available in schools. The majority of the respondents were females: $38.6 \%$ had taught Agriculture in schools located in urban areas, while $31.8 \%$ had taught in rural-located schools. Half $(\mathbf{5 0 . 0 \% )}$ of the student teachers had taught for a period of eleven to twenty years while more than two-thirds had taught for less than ten years. The results revealed that student teachers were deficient in appropriate skills and knowledge for making use of available computer technology. Furthermore, the results indicated teachers have minimal knowledge and skills on computer and then learn how to use computers through in-service training, short courses and workshops. Based on the findings, the pre-service curriculum needs to be improved so that teachers can be more competent in using advanced technology to improve students' learning. In-service courses on ICT should be provided to all teachers as a requirement to enhance teachers' technical skills in the field.
\end{abstract}

Key words: Computers, student-teachers, Agriculture, availability, accessibility and usability.

\section{INTRODUCTION}

Since independence, Botswana's education system has undergone changes and reforms in terms of curriculum, infrastructure, schools' enrolment and teachers' education (Sebobi, 2012; Maundeni and Mookodi, 2004). The Revised National Policy on Education (1994), which is the guiding policy of education, has advanced the adoption and integration of science and technology in education. In line with this policy, computers have been introduced in schools as information and communication technology (ICT) awareness to students. According to www.waikato.ac.nz, computer technology is the education of the hardware and software that form the foundations of modern computer systems of several education programmes. The curriculum that infuses computer education has

*Corresponding a uthor. E-mail: khulela @bca.bw, hulela una mi@ya hoo.com. Tel: 0026771916092.

Authors agree that this article rema in pemanently open access under the terms of the $\underline{C}$ reative Commons Attribution License 4.0 Intemational Lic ense 
been put in place for schools since the late 1990s when the policy was first implemented. Some short courses were done to up-grade and enhance teachers' knowledge and skills on computer technology. Furthermore, preservice programs infusing computer courses have also been introduced in tertiary and higher education to prepare teachers who are capable of integrating technologies in teaching.

The use of computers in teaching and learning seems to have become popular as many educators use a variety of information and communication technologies (ICTs) like PowerPoint, Web CT, CD-ROM, www Multimedia, Moodle to enhance learning. Such development associated with computer education is a meaningful one. According to Sjøberg (2002), nowadays, societies in various countries are "dominated and 'driven' by ideas and products from science and technology (S\&T) and it is very likely that the influence of science and technology on our lives will continue to increase in the years to come". Shailaja (2013) stated that computers can be used in education for different purposes like programming as a developmental or authoring tool, programmed instruction, simulating experiments and as productivity tools. The Office of Technology Assessment (1995), as cited by Mishra and Cavanaugh, (2008), has found that several teachers were still reported to make minimal use of technology in the learning environments. According to Adeoye and Popoola (2011), accessibility of resources in education is important because at times the resources may be available but not accessed by the users; thus becoming meaningless. Setzer and Monke (2001) found that the majority of teachers lack confidence in computer technologies.

Setzer (2000) argued for and against the use of computers by children in schools and at home. The author pointed out that when children use computers at an early age both at home and in schools, there are several positive implications in the society and for education. The author noted that among other things, computers 'improve both teaching and students' achievement', since the literacy skill is taught as early as possible to ensure students are not left behind. Secondly, the adoption of such a machine in schools would require high support from the business community as schools alone would not be able to raise enough funds to afford enough computers for all their children. Thirdly, computers in education encourage "work force competitiveness in an increasingly high-tech world", thus making the learning of computer skills to be a priority. Fourth, 'working with computers, particularly the use of internet would connect students to their teachers and a wide network of professionals around the globe (Setzer, 2000). Arguing against the use of computers by children at an early age, Setzer (2000) pointed out that the danger and worst influence of computers on children included what the author termed "cosmetics" and the "video game" effects that affect the child's behaviors. The authors therefore concluded that the use of computers in education particularly by young children and adolescents has influence and appeared to be a way to computerize nations.

Using Dede's (2006) model questions as framework for the views of teachers about computers' availability, affordability and usability provides an insight into the current status of computers in schools. Computers may be available in schools and not necessarily accessible for use by teachers, thus not benefiting learners. Similarly, computers may be available and accessible but not user friendly. The questions raised by Dede (2006) are a powerful interrogative form or functions to create an understanding of the environment under which teachers of agriculture work on in schools. Dede's model questions are; (i) how can schools afford to purchase enough multimedia-capable, internet-connected computers so that a classroom machine is always available for every two to three students? (ii) How can schools afford enough computers and telecommunications to sustain new models of teaching and learning? (iii) How can many educators disinterested in or phobic to computers be induced to adopt new technology-based models of teaching and learning? (iv) How do we prove to communities that new, technology-based models of teaching and learning are better than current instructional approaches? (v) How can educational technology increase equity rather than widen current gaps between "haves" and "have-nots?" If computers and ICTs are available in schools for teaching and learning of Agriculture, to what extent are they available, accessible and used by teachers of Agriculture? Such questions posed a need to examine the situation in schools of which the researchers set to establish the extent to which computers were available and used in secondary schools in Botswana. The outcome of which would inform the stakeholders on availability of computers in schools, sustainability of teaching and learning methods, the teachers' phobia in using computers, and the relevance of computers approaches. Although Dede's questions seem to draw the attention of stakeholders on issues related to resource availability, it is also important to get the perceptions of teacher practitioners on the availability, accessibility and usability of computers in instruction.

A study conducted by Zhu (2010) in China showed that in this world of digital and knowledge, the education sector is faced with challenges to move away from traditional teaching towards adopting a more innovative strategy. The author further reported that the situation "raises a great demand for the transformation of teachers' roles from traditional knowledge transmitter to a new set of roles" (Zhu, 2010:72). To address this kind of a challenge, Davis and Roblyer (2005) report that there is a need to create a model that incorporates virtual schooling in the pre-service teacher education with an appropriate assessment of the significant innovation to improve teachers' preparation at an initial stage. A study 
conducted by Hadjerrouit (2008) in Norway advocated for the blended learning in higher education as new innovative information technologies based on solid learning theory and pedagogical strategies based on research findings. Similarly, a study conducted in Ghana has alluded to the fact that the tertiary education sector has advanced in the deployment and use of information technologies (Mangesi, 2007). According to Mangesi in Ghana, the universities have their own separate policy, which includes ICTs levy for students to have at least 24 $\mathrm{h}$ access to computer laboratories with broad band connection. This gives an opportunity for students to get used to using computers all the time.

In a study conducted by Totolo (2009), it was reported that the use of Information Technology (IT) in schools has influenced some changes in the digital scholarship, which is a modern technology applied in teaching, learning and research activities. The author, however, found that the challenge in adopting technology in education was associated with factors such as computer anxiety, digital literacy and lack of ease of use of the computers. However, these factors should not act as deterrence to the introduction of computers in schools because they could be overcome easily. This is true because anxiety problems and lack of confidence may affect teachers, but students may not face such problems; rather they would welcome them with enthusiasm as a new thing in their lives. This is supported by Bose (2009) who found that ICT at an early age is necessary but more important would be one with relevant and appropriate resources to enhance the development of young children holistically. According to her, an appropriate ICT program should provide educational concepts to assist in development of problem solving skills and creativity of children. According to Totolo (2009), countries are currently investing on computer and ICTs to enhance the education sector. Based on literature reviewed, some research work is still needed on ICTs in education particularly in developing countries, in order to examine and ascertain the computer availability, accessibility and usability of ICTs. Therefore, the purpose of this study is to examine the perceptions of student teachers of Agriculture about the availability, accessibility and usability of computers and ICTs in secondary schools where they taught before. The specific objectives of this study include:

(i) To describe the personal characteristics of BSc Agric. Education student teachers

(ii)To describe the availability, accessibility and frequency of using ICT services by teachers in secondary schools.

(iii) To describe student teachers' perceptions regarding computers in schools.

(iv) To describe approaches currently used to prepare Agriculture teachers on computers and ICTs.

\section{METHODOLOGY}

This study used a descriptive research design that employed closed ended questionnaire to gather data from fifty one student teachers of Botswana College of Agriculture (BCA), who have Bachelor of Science degree in Agricultural Education. The group was enrolled in the AEB 223 course during the first semester of the 2013/2014 academic year. The purposively selected group comprises both preservice and in-service students at Botswana College of Agriculture. The group was selected because; (i) had previously taught in junior secondary schools prior to enrolling into the BSc Agric education programme at BCA, (ii) were more knowledgeable about the use and adoption of computers in schools. (iii) were in the proximity to the researchers; (iv) comprised a diverse members that provided appropriate data from different districts in the country including rural and urban schools $(\mathrm{v})$ had taught both practical and theory aspects of the subject in schools and, (vi) were willing to provide data about the availability, accessibility and usability of computers in schools. The group was deemed suitable to provide appropriate data about the status of computers in schools in terms of variables studied.

A questionnaire was used to collect data. The first part of the questionnaire required the student teachers to provide their personal characteristics. Part two of the questionnaire requested the student teachers to indicate on a checklist with a "Yes" or "No" answer for computers available. Furthermore, student teachers were also asked to indicate whether computers were accessible by indicating "Yes = accessible" or "No = not accessible"; and further the frequency of usage of each computer service by teachers was indicated on a 4-point- Likert- type scale: 1 = Not used; 2 = Rarely used; 3 = Occasionally used, and $4=$ Always used.

The face and content validity of the questionnaire was determined by the Agricultural Education experts in the Department of Agricultural Economics, Education and Extension (AEE) at Botswana College of Agriculture (BCA). Among other factors considered by the experts in reviewing the content validity of the questionnaire, as advised by Fitzpatrick (1983), were the relevance of items to behaviors measured in this study, clarity of items, relevance to the domain of ICTs and the technical quality of items for gathering appropriate data. The suggestions gathered were used to modify the questionnaire.

To determine the internal consistency of the questionnaire in collecting reliable data, the researchers administered a pilot study at Chamabona Junior Secondary School in Mathangwane village in the Central District. Five Agriculture teachers participated in the pilot study. The test -retest form of reliability was used whereby teachers were given the instrument twice within an interval of a period of two weeks to respond to items. The instrument was found to yield approximately the same results on two different occasions. The Cronbach's Alpha coefficients for part 2 'teachers' level of agreement' and the "computers frequency of use" were 0.73 and 0.85 , respectively. The re-test Cronbach's Alpha coefficients results for the instrument yielded 0.75 and 86 respectively, which proves the consistency of the instrument.

Permission was sought from the Ministry of Education and Skills Development (MEoSD) as the employer of the student teachers. A letter was attached to the questionnaire explaining the importance of the study, the value of teacher's participation in such research studies, assurance on the confidentiality of the data gathered, and the contribution of the outcomes of the study to the classroom instructions.

To collect data, fifty one questionnaires were distributed to a census of 51 student teachers. The questionnaires were hand delivered by one of the researchers to the students as they disembarked from the college hall when they finished the AEB 223 examination. Forty-four (86\%) out of 51 Agricultural Education student teachers surveyed willingly completed the survey. Out of the 44 student teachers, $39(87 \%)$ completed and returned the survey on the same day, while $5(11 \%)$ opted to complete and return the completed survey questionnaire on the next day. At least $97 \%$ response rate was achieved, which provides the sample population for the study. The results of the study were generalized 
Table 1. Demographic information about teacher respondents.

\begin{tabular}{|c|c|c|c|}
\hline Gender & & Frequency & Percent \\
\hline & Male & 20 & 45.5 \\
\hline & Female & 23 & 52.3 \\
\hline & Missing & 1 & 2.3 \\
\hline \multicolumn{4}{|l|}{ Location of school } \\
\hline & Urban & 17 & 38.6 \\
\hline & Rural & 14 & 31.8 \\
\hline & Semi-urban & 13 & 29.5 \\
\hline \multicolumn{4}{|c|}{ How long have you been teaching? } \\
\hline & Less than 10 years & 16 & 36.4 \\
\hline & 11 to 20 years & 22 & 50.0 \\
\hline & 21 to 30 years & 1 & 2.3 \\
\hline & 41 to 50 years & 5 & 11.4 \\
\hline \multicolumn{4}{|l|}{ How old are you? } \\
\hline & Between 21 and 30 years old & 12 & 27.3 \\
\hline & Between 31 to 40 years & 24 & 54.5 \\
\hline & between 41 and 50 years & 8 & 18.2 \\
\hline \multirow[t]{3}{*}{ Last Certificate obtained } & Diploma in secondary education & 16 & 36.4 \\
\hline & Diploma in Agric Education & 14 & 31.8 \\
\hline & Botswana General Certificate of Secondary Education & 14 & 31.8 \\
\hline \multicolumn{4}{|l|}{ Position currently held } \\
\hline & Teacher [Potential teacher] & 7 & 15.9 \\
\hline & Senior teacher II & 23 & 52.3 \\
\hline & Senior teacher I & 6 & 13.6 \\
\hline & Pre-service teacher & 8 & 18.2 \\
\hline
\end{tabular}

to the 44 AEB 223 student teachers in the second semester of the $2012 / 2013$ academic year who participated in the completion of the survey. The latest version for Statistical Package for the Social Sciences (SPSS) was used to analyze data into descriptive statistics to respond to the study objectives.

\section{RESULTS AND DISCUSSION}

Table 1 presented personal information of the Bachelor of Science degree student teachers currently at Botswana College of Agriculture, who were enrolled in the course AEB 223 (Educational Measurements and Testing) during the first semester of the academic year 2013/ 2014. This group had the experience of teaching after their diploma and during supervised teaching practice. The personal information gathered included gender, location of school where the teacher taught before or during their teaching practice, experience in teaching, age, position held during the teaching and the last certificate obtained before joining the Botswana College of Agriculture for a Bachelor of Science degree in
Agricultural Education (BSc. Agric Edu).

\section{Objective 1: Personal characteristics of student teachers}

The results showed that $53 \%$ of the respondents were females, showing that there were slightly more female Agricultural Education student teachers than males. Close to forty percent $(38.6 \%)$ of the group had taught Agriculture in schools located in urban areas and close to two-thirds (31.8\%) had the experience of teaching in rural- located schools. The results in Table 1 also showed that fifty percent of the student teachers had taught for a period of 11 to 20 years while more than two-thirds $(36.4 \%)$ had taught for less than 10 years. In terms of age, $54.5 \%$ of the student teacher respondents were in the age between 31 and 40 years old, while close to twenty percent $(18.2 \%)$ were in the age range between 41 and 52 years. Slightly above two third (36.4\%) of the group held Diploma in secondary education, before 
Table 2.Student teachers' perceptions regarding computers in education.

\begin{tabular}{|c|c|c|c|}
\hline & $\mathbf{N}$ & Mean & SD \\
\hline (1) Computers improve both teaching and student achievement & 44 & 4.60 & 0.79 \\
\hline (2) Computer literacy should be taught as early as possible & 44 & 4.79 & 0.41 \\
\hline (3) Computer technology programs require support from the business community & 43 & 4.26 & 0.69 \\
\hline $\begin{array}{l}\text { (4) Computers make tomorrow's work force competitive in an increasingly high-tech world and learning } \\
\text { computer skills must be a priority }\end{array}$ & 44 & 4.55 & 0.50 \\
\hline $\begin{array}{l}\text { (5) Working with computers - particularly using the Internet - brings teachers valuable connections with their } \\
\text { students and other professionals in the teaching profession }\end{array}$ & 44 & 4.53 & 0.59 \\
\hline $\begin{array}{l}\text { (6) Working with computers - particularly using the Internet - brings teachers to a wider network of } \\
\text { professionals around the globe. }\end{array}$ & 44 & 4.57 & 0.50 \\
\hline (7) The introduction of computers in education gives chance to improve classroom instructions & 44 & 4.44 & 0.62 \\
\hline $\begin{array}{l}\text { (8) Teachers who had learned how to program a computer and use very concrete computer models to teach } \\
\text { their subject matter in class about learning enhance their powers as psychologists and epistemologists. }\end{array}$ & 44 & 4.34 & 0.60 \\
\hline $\begin{array}{l}\text { (9) Teachers who had learned how to program a computer could use very concrete computer models to } \\
\text { enhance students learning }\end{array}$ & 44 & 4.32 & 0.77 \\
\hline (10) Teachers who had learned & 44 & 3.81 & 1.12 \\
\hline $\begin{array}{l}\text { (11) I believe that the computer as a writing instrument offers children an opportunity to become more like } \\
\text { adults }\end{array}$ & 43 & 3.88 & 0.91 \\
\hline $\begin{array}{l}\text { (12) The computers' presence in schools bring both teachers and children to a more humane relationship with } \\
\text { mathematics }\end{array}$ & 42 & 4.02 & 0.68 \\
\hline $\begin{array}{l}\text { (13) The computer brings it into the land of the rich activities which could, in principle, be truly engaging for the } \\
\text { novice and the expert teachers }\end{array}$ & 43 & 4.05 & 0.62 \\
\hline $\begin{array}{l}\text { (14) The computer can be seen as an engine that can be harnessed to solve the problems that face schools as } \\
\text { they exist today }\end{array}$ & 43 & 4.28 & 0.77 \\
\hline (15) Computation can be more than a theoretical science and a practical art & 44 & 4.25 & 0.61 \\
\hline (16) Comput & 44 & 3.89 & 0.85 \\
\hline oersonal vision of the world & 44 & 3.86 & 1.00 \\
\hline (18) Computers can be & 43 & 3.93 & 0.91 \\
\hline (19) Teachers have entered a passionate & 44 & 3.50 & 1.11 \\
\hline (20) There is a passionate love affair between teachers and computers & 43 & 3.69 & 0.96 \\
\hline $\begin{array}{l}\text { (21) The best uses of computers that I have seen in homes are so much better than what is being done with } \\
\text { computers in schools }\end{array}$ & 43 & 3.55 & 0.96 \\
\hline $\begin{array}{l}\text { (22) Computer learning experiences give the teacher chance to become more aware of its learning culture and } \\
\text { a chance to work with }\end{array}$ & 44 & 3.71 & 0.98 \\
\hline
\end{tabular}

enrolling in Agricultural Education program at Botswana College of Agriculture (BCA).Equal proportions of almost two third (31.8\%) held the Botswana General Certificate of Secondary Education and Diploma in Agricultural Education certificates prior to enrolling in Botswana College of Agriculture for their degree program. This means that the group surveyed was made up of mainly students with different backgrounds. This would imply different backgrounds on computer accessibility and usage since they taught in different schools and an equal number of them were directly from senior secondary schools (Table 1).

\section{Objective 2: Student teachers' perceptions regarding computers in education}

Table 2 shows the statements from the arguments regarding the use of computers in school going children.
The surveyed group was asked to indicate their level of agreement or disagreement with the statements as borrowed from Setzer (2000) pertaining to how computers are used in education, their values, benefits in teaching and learning as well as how computers are perceived to contribute to the education of children. As shown by the means computed from the data gathered, majority of the means were highly above the average mean of 2.5 in a scale of 1 to 5 used for rating the benefit of computers to children. The highest statistical mean was recorded on "Computer literacy should be taught as early as possible" (Mean $=4.79 ; \mathrm{SD}=0.41$ ) followed by "Computers improve both teaching and students' achievement" (Mean $=4.60: \mathrm{SD}=0.79$ ). This means the student teacher respondents highly agreed to the statements. The least mean was computed on the statement that "Teachers have entered into a passionate and enduring love affair with computer technology" (Mean $=3.50$ ' SD $=1.11$ ). The results from Table 2 showed that the majority of the 
Table 3. Mode of learning computers by Agriculture Science teachers.

\begin{tabular}{lccc}
\hline Teachers of agriculture learn computers through & N & Mean & SD \\
\hline (1) Playing games in the computer? & 44 & 3.59 & 1.04 \\
(2) In-service workshops & 44 & 3.97 & 0.73 \\
(3) Pre-service education & 43 & 3.63 & 1.02 \\
(4) Through trial and error as I type my work & 44 & 3.75 & 0.92 \\
\hline
\end{tabular}

student teachers agreed with all of the twenty-two constructs that computers are important for teachers and students to improve education. This positive response reinforces the importance of computers in education and perhaps the recognition of Botswana's Vision 2016 - 'an educated, informed nation'.

\section{Objective 3: Methods used to prepare teachers on computers and ICT services}

Table 3 presented results on methods used to prepare teachers to use computers in teaching. The student teachers were asked to indicate ways in which they learnt how to use computers in teaching Agriculture in schools. Results showed the highest statistical mean (3.97: SD = 0.73) on the statement which indicated that teachers learn computers through "in-service workshops" followed by the statement "I learn computers through trial and error as I type school work"(Mean= 3.75; SD = 0.92). The results mean that teachers graduate from their training with minimal knowledge and skills on computers and then learn how to use computers through in-service training and on the job training as they perform their teaching. This could also be close to the reality on ground since computers were just introduced when they were in the field. According to Bose (2009), computers were better off learnt at an early stage of children's development to minimize the challenge of phobia as raised in one of the questions posed by Dede (2000) and low self-efficacy as found by Sam et al. (2005), which may change when people use computers later in life (Table 3).

\section{Objective 4: Technologies and ICT services available, accessible and usable in schools}

Table 4 showed a list of different technologies and forms of ICT services available, accessible and usable in schools to facilitate the teaching and learning of Agriculture. The results in Table 4 showed that majority (76\%) of the surveyed student teacher respondents indicated that ICT was available in schools, $63 \%$ showed it was accessible and usable ((Mean $=2.74 ; \mathrm{SD}=0.91)$. The results showed that spreadsheet was 84.1\%; PowerPoint (88.6\%) and typing Agricultural Science notes and communication were $81.8 \%$. With regard to accessibility,
$77.3 \%$ indicated that they have access to ICTs for "Typing Agricultural Science notes", followed by $75 \%$ on spreadsheet. Usability of the technology as measured by statistical means showed that the respondent indicated "Preparing the teaching timetable" (Mean $=3.57$; SD= 0.82) followed by "Typing quizzes, monthly tests and examinations" [word processing] (Mean $=3.48$; $\mathrm{SD}=$ $0.85)$. These results could be a true reflection of what transpires in secondary schools as the technology and ICT services studied refer to the basics of the ICTs in schools. Generally, teachers were expected to type their students' work and keep record of names of their students in computers. Therefore, the results of the study are a true reflection of what is in schools. Schools have secretaries who type examinations and other school notes; thus student teachers may be referring to that service in terms of access and usability. It will therefore be appropriate to conduct a comprehensive study to establish the extent to which teachers are able to utility computers and ICTs services in education. Based on the results, availability of the resources in schools does not necessarily imply that these resources are used by all teachers to teach or facilitate their lessons.

\section{DISCUSSION AND CONCLUSION}

The results revealed that there were more females than males in the group that was studied. The group comprises $38.6 \%$ student teachers who had taught Agriculture in schools located in urban areas and $31.8 \%$ student teachers had taught in rural-located schools. Majority of the student teachers were in their youthful age, which is why they were awarded scholarship by the government to pursue their bachelor's degree. A very high proportion of respondents indicated that "Computer literacy should be taught as early as possible", which is supported by the results of Bose (2009). Student teachers perceived literacy skills important in their career; hence they indicated the need to acquire skills and knowledge to enhance students' learning.

The results further showed that there were two forms through which teachers learn how to use computers: "inservice workshops" and "through trial and error as they type school work". However, the study did not indicate whether or not student teachers have taken some computer courses in their current studies. Based on the 
Table 4. Availability, access and frequency of use of computers in schools.

\begin{tabular}{|c|c|c|c|c|c|c|c|}
\hline \multirow{2}{*}{$\mathrm{S} / \mathrm{N}$} & \multirow{2}{*}{ Kinds of technology/ICT services } & \multicolumn{2}{|c|}{ Availability } & \multicolumn{2}{|c|}{ Accessibility } & \multicolumn{2}{|c|}{$\begin{array}{l}\text { Frequency of } \\
\text { Use }\end{array}$} \\
\hline & & Yes & No & Yes & No & Mean & SD \\
\hline 1. & $\begin{array}{l}\text { Typing quizzes, monthly tests and examinations [word } \\
\text { processing] }\end{array}$ & $33(75.0)$ & $10(22.7)$ & $29(65.9)$ & $13(29.5)$ & 3.48 & 0.85 \\
\hline 2. & Developing PowerPoint to teach & $3375.0)$ & 10 22.7) & $29(65.9)$ & $11(25.0)$ & 2.16 & 1.03 \\
\hline 3. & Typing agricultural science notes & $36(81.8)$ & $8(18.2)$ & $34(77.3)$ & $8(18.2)$ & 2.93 & 0.89 \\
\hline 4. & Keeping records [data base] & $33(75.0)$ & $11(25.0)$ & $28(63.6)$ & $13(29.5)$ & 2.96 & 0.94 \\
\hline 5. & Preparing the teaching timetable & $35(79.5)$ & $9(20.5)$ & $30(68.2)$ & $10(22.7)$ & 3.57 & 0.82 \\
\hline 6. & Accessing internet & $35(79.5)$ & $9(20.5)$ & $24(54.5)$ & $18(40.9)$ & 2.98 & 0.99 \\
\hline 7. & Computing students' test marks for tests and CA [spreadsheet] & $37(84.1)$ & $7(15.9)$ & $33(75.0)$ & $9(20.5)$ & 3.21 & 0.90 \\
\hline 8. & Presentations during agricultural subject workshops (ppt) & $39(88.6)$ & $5(11.4)$ & $30(68.2)$ & $12(27.3)$ & 2.84 & 0.89 \\
\hline 9. & Developing and publishing information [ Publisher] & $29(65.9)$ & $15(34.1)$ & $21(47.7)$ & $20(45.5)$ & 2.34 & 0.91 \\
\hline 10. & Searching research articles & $35(79.5)$ & $9(20.5)$ & $28(63.6)$ & $14(31.8)$ & 2.73 & 0.87 \\
\hline 11. & Communication purposes & $36(81.8)$ & 8 (18.2) & $30(68.2)$ & $12(27.3)$ & 2.59 & 0.92 \\
\hline 12. & Access the library catalogue & $26(59.1)$ & $18(40.9)$ & $24(54.5)$ & $18(40.9)$ & 2.02 & 0.99 \\
\hline 13. & Enabling Linux operations & $29(65.9)$ & $14(31.8)$ & $23(52.3)$ & $16(36.4)$ & 1.91 & 0.86 \\
\hline \multirow[t]{2}{*}{14.} & Web browsers for windows & $29(65.9)$ & $12(27.3)$ & $26(59.1)$ & $14(31.8)$ & 2.59 & 0.87 \\
\hline & Total average & $33(76 \%)$ & & $28(63 \%)$ & $14(30 \%)$ & 2.74 & 0.91 \\
\hline
\end{tabular}

results, it would be appropriate for teachers' preparation programs in tertiary and higher institutions to consider developing curriculum infusing ICT courses to prepare teachers rather than conducting in-service workshops. For those already in field, there is need to run short courses in collaboration with the higher institutions of learning which prepare teachers. The results also revealed that respondents agreed that computer technologies were available, accessible and used in schools. For example, $84.1 \%$ indicated that spreadsheet is available in schools, $88.6 \%$ indicated PowerPoint, while 81.8\% agreed to typing Agricultural Science notes and communication. With regard to accessibility of ICT resources, more than $70 \%$ agreed to use computers for typing Agricultural Science notes, and spreadsheet for data analysis. Respondents also agreed that they used technology in schools.

The overall results show that student teachers agreed that computers were available, accessible and used to support their teaching career. However, what is not known is the extent to which these computers were used by teachers and whether they are adequate or not to all. Student teachers' responses were based merely on availability; perhaps there will be need to repeat the study and make further analysis of the ratio of students per computer.

\section{Conflict of Interests}

The authors have not declared any conflict of interests.

\section{REFERENCES}

Adeoye S, Popoola SO (2011). Teaching effectiveness. availability. accessibility and use of library and information resources among teaching staff of schools of nursing in Osun and Oyo States, Nigeria. Library Philosophy and Practice http://www.webpages.uidaho.edu/ mbolin/adeoye-popoola.htm

Bose K (2009). Developmentally Appropriate Technology in Early Childhood (DATEC) in Botswana: In-Service Teachers' Perspectives. Int. Elect. J. Elementary Edu. 1(3):218-231.

Davis NE, Roblyer MD (2005). Preparing Teachers for the "Schools That Technology Built": Evaluation of a Program to Train Teachers for Virtual Schooling. Journal of Educational Research. J. Res. Technol. Education. 37(4):399-409.

Dede C (2006). Six Challenges for Educational Technology George Mason http://www.learningdomain.com/6_challenges.IT.pdf

Fitzpatrick AR (1983). The Meaning of Content Validity. Applied Psychological Measurements Inc. 7(1):3-13. http://conservancy.umn.edu/bitstream/101621/1/v07n1p003.pdf

Hadjerrouit S (2008). Towards a Blended Learning Model for Teaching and Learning Computer Programming: A Case Study. Towards a Blended Learning Model for Teaching and Learning Computer Programming. Informatics in Education. 7(2):181-210 @ 2008 Institute of Mathematics and Informatics, Vilnius

Maundeni T, Mookodi G (2004). Introduction: Critical Social Challenges in Contemporary BotswanaPula: Botswana. J. Afr. Stud. 18(1).

Mishra PD, Cavanaugh K (2008). Teaching, Learning theory and Technology. The new forums press technology in the classroom series/ 57.

Sam HK, Othman AEA, Nordin ZS (2005). Computer Self-Efficacy, Computer Anxiety, and Attitudes toward the Internet: A Study among Undergraduates in Unimas. Edu. Technol. Soc. 8(4):205-219.

Sebobi EM (2012). Challenges in the teaching of Botswana General Certificate of Secondary Education Art and Design Curriculum. http://wiredspace.wits.ac.za/handle/10539/11290

Setzer VW (2000). Computers in education a review of arguments for the use of computers in elementary education. http://www.ime.usp.br/ vwsetzer/review.html

Setzer VW, Monke L (2001). Challenging the applications: an alternative view on why, when and how computers should be used in education," In: Muffoletto, R. (Ed.), Education and Technology: Critical and Reflective Practices,. Cresskill, New Jersey: Hampton Press. pp. 141-172. http://www.ime.usp.br/ vwsetzer/comp-ineduc.html

Shailaja M (2013). Problems of computer teachers at secondary school 
level. Conflux J. Edu. ISSN 2320-9305 1(1):155-205.

Sjøberg S (2002). Science and Technology Education. Current Challenges and Possible Solutions. To be published in Jenkins, Edgar (ed) (2002) Innovations in Science and Technology Education Vol VIII Paris, UNESCO. http://folk.uio.no/sveinsj/STE_paper_Sjoberg_UNESCO2.htm

Totolo A (2009). An analysis of information technology adoption situation in Botswana secondary schools and its impact on digital scholarship initiatives in institutions of learning. http://www.ais.up.ac.za/digi/docs/totolo_paper.pdf http://www.ais.up.ac.za/digi/docs/totolo_paper.pdf
Zhu C (2010). Teacher roles and adoption of educational technology in the Chinese context. J. Edu. Res. Online. 2(2):72-86. http://www.j-er-o.com/index.php/jero/article/viewFile/80/91 